\title{
Effect of Moringa Oleifera Leaf Meal (Molm) on the Growth, Carcass, Heamatology and Biochemical Parameters of Rabbits
}

\author{
Ghomsi MOS ${ }^{1}$, Enow $\mathrm{JT}^{1}{ }^{1}$, Etchu $\mathrm{KA}^{1}{ }^{*}$, Tientcheu $\mathrm{BL}^{1}$, Enamou ${ }^{1}{ }^{1}$, Chouengouong $\mathrm{TM}^{1}$, Mongo \\ $\mathrm{BG}^{1}$, and Bayemi $\mathbf{P H}^{\mathbf{1}}$ \\ ${ }^{1}$ Institute of Agricultural Research for Development (IRAD), BP 2067 Yaoundé, Cameroun
}

Received: 02 March, 2017; Accepted: 26 April, 2017; Published: 08 May, 2017

*Corresponding author: Etchu A K, Institute of Agricultural Research for Development (IRAD), Yaoundé, Cameroon, Tel no: (+237) $677708069 / 6991$ 57 384; E-mail: etchu74@gmail.com

\begin{abstract}
An experiment was conducted with 30 mixed bred rabbits $(6$ to 8 weeks old) averaging 592g to assess the performance, haematology, serum biochemistry, carcass and organ weights of growing rabbits fed graded levels of dried Moringa oleifera Leaf Meal (MOLM) of $0 \%, 25 \%$, and $50 \%$, as a replacement of Soya Bean Meal (SBM) and groundnut cake in 8-week feeding trial. Feed consumption and weight gain were monitored. Blood samples were collected from the animals through the ear vein for haematology and serum biochemistry, while weight of cut parts and visceral organs were collected from the animals after they were stunned and sacrificed after the 8-week feeding trials and weighed. Results showed that there were significant differences $(p<0.05)$ in the value obtained for weight gain, feed conversion ratio, total protein and White Blood Cell (WBC). While the results of carcass and organ weight showed significant $(P<0.05)$ difference in values obtained for live weight, dress weight spleen, head and kidney. While there was no significant difference among the blood constants (VGM and MCHC). Among the leukocyte differential counts examined, lymphocytes, monocytes and eosinophils were not significantly different among the dietary treatments. The results suggest that MOLM possess good dietary protein quality for optimal growth of rabbits and be incorporated in the rabbit's diets up to $25 \%$ inclusion levels without any detrimental effects on the performance, haematology, serum biochemistry and carcass and organ weights of growing rabbits.
\end{abstract}

Keywords: Moringa leaf; Rabbits; Growth; Carcass; Heamatology

\section{Introduction}

The rabbit (Oryctolagus cuniculus) is the most productive meat producing among all domesticated animals. The feeding habits offer no appreciable competition with man. This is because it can subsist on green as basal diets. In addition to this, rabbits have a number of other characteristics that might be advantageous to subsistence farming system, such as their small body size, short generation interval with a relatively short gestation period of 30-31days. The use of forage and other agro industrial by-products have become an area of interest for many researchers because of the challenges posed by the high cost of conventional feedstuff [1]. In Cameroon, rabbit production is mainly practiced under traditional management systems in rural areas and so has not yet attained its full production potential [2].

Recently, there has been interest in the utilization of Moringa (Moringa oleifera) commonly called horse radish tree or drum stick tree, as potential inexpensive protein source for livestock feeding. The nutritional qualities of Moringa oleifera are excellent, which constitutes a source of high quality forage for animals. Also, these leaves are browsed by ruminants and poultry because of its high protein and minerals, by guinea pigs, by rabbits and by cricetoms [3-5].

Serum biochemical analysis is an established means of assessing Toxicological, health and carcass quality status of animal on feeding trials since ingestion of dietary components has measurable effect on carcass quality and may be considered as an appropriate measure of long term nutritional status. This study was therefore, carried out to investigate the effect of feeding graded levels of Moringa oleifera leaf meal on the growth, carcass, haematology and serum biochemical parameters of rabbits.

\section{Materials and Methods}

\section{Study Site}

The study was conducted at the experimental farm of the Institute of Agricultural Research for Development (IRAD) Nkolbisson, situated in the western suburbs of Yaoundé, Cameroon. This centre is located at $3^{\circ} 86$ longitude North and $11^{\circ} 5$ latitude East. This agro-ecological zone is characterized by minimum temperatures of $19^{\circ} \mathrm{C}$ and maximum of $29^{\circ} \mathrm{C}$, a bimodal rainfall of 1500 to $2500 \mathrm{~mm} /$ year and a relative humidity that varies between $70 \%$ and $90 \%$. The climate is sub-equatorial marked by four seasons [6].

\section{Test Ingredient}

Moringa leaves have been Harvested from agro-forestry plot of Irad ekona, by proaning and hand picking, solar dried for 
2 days. Then oven dried at a temperature of $50^{\circ}$ Centigrade for one hour and air dried under shade to prevent the leaves from being denatured until they will be crispy to touch. The leaves were thereafter crushed with hammer mill before incorporation in the test diets. Three (3) experimental diets were formulated. Diet 1 designated as T0 served as the control diet and contains no (0\%) Moringa oleifera leaf meal. Diet 2 designated as T1, Diet 3 as T2, containing Moringa oleifera leaf meal at the levels of $25 \%$ and $50 \%$ as a replacement of protein contain by soya bean meal (SBM) and groundnut cake respectively (Table 1).

\section{Animal material, Experimental diets and Experimental design}

\begin{tabular}{|c|c|c|c|}
\hline \multirow[b]{2}{*}{ Ingredients (kg) } & \multicolumn{3}{|c|}{ Rations } \\
\hline & T0 & T1 & T2 \\
\hline Vitamin premix & 1.5 & 1.5 & 1.5 \\
\hline Bone Meal & 2 & 2 & 2 \\
\hline $\begin{array}{l}\text { Palm Kernel Cake } \\
\text { (PKC) }\end{array}$ & 17 & 17 & 17 \\
\hline Fish meal & 5 & 5 & 5 \\
\hline Groundnut cake & 12 & 7 & 2 \\
\hline Soybean Meal (SBM) & 13 & 8 & 3 \\
\hline MOLM & 0 & 10 & 20 \\
\hline Corn & 20 & 20 & 20 \\
\hline Wheat Bran & 30 & 30 & 30 \\
\hline Salt & 0.5 & 0.5 & 0.5 \\
\hline Total & 100 & 100 & 100 \\
\hline \multicolumn{4}{|c|}{ Calculated chemical composition } \\
\hline Crudeprotein (\%) & 24.1 & 22.28 & 20.46 \\
\hline $\begin{array}{l}\text { Metabolisable energy } \\
\text { (Kcal/kg) }\end{array}$ & 2600 & 2640 & 2680 \\
\hline
\end{tabular}

$\mathrm{T} 0=0 \%$ Moringa oleifera leaf meal, $\mathrm{T} 1=25 \%$ Moringa oleifera leaf meal, $\mathrm{T} 2=50 \%$ Moring a oleifera leaf meal

\section{Experimental Design and Management of Animals}

Thirty weaners rabbits of mixed breeds and sex were use in this study. The animals were between 6 and 8; weeks old and with initial average live weight of 571- 614g. The rabbits were randomly allocated to three (3) treatment diets (T0, T1, T2) with each treatment having five replicates of two rabbits. The animals were house in cages and given an adaptation period of one week to the experimental diets. During this period, they were de-wormed (IVERMET o-1, USO VETERINARIO VMD, Belgium) and given antibiotics (Oxykel 80, KELA N.V, Belgium) against bacterial infections. They were also given an anti-stress (Amin'Total LAPROVET, BP, Cedex 2, France) each time they were manipulated. Routine management practices were carried out during the work. Feed and fresh water was provided ad libitum. Small quantities of 24-h wilted forage were also providing each day.

\section{Data Collection}

The rabbits were weighed weekly using weighing balance, before feed was given. Feed intake was obtained by deducting left-over feed from the quantity offered. The data were used to calculate daily weight gain, daily feed intake and feed conversion ratio (FCR). The FCR was calculated by dividing the daily feed intake by the metabolic weight depend on the amount of metabolically active tissue in the body, rather than total body weight; body weight ${ }^{0.75}$ is generally used to calculate the weight of active tissue.

At the end of the feeding period, the animals (three per treatment) were starved of feed for 24 hour and thereafter slaughter.

\section{Calculated parameters}

The calculation of certain parameters was done as follows:

-Simple consumption index = (feed consumption) / (weight gain)

-Feed efficiency relative to metabolic weight $=$ (Feed consumption $)$ / Weight Gain 0.7

\section{Characteristics evaluation}

After termination of the feeding experiment, three representative rabbits randomly chosen from each group were fasted for $24 \mathrm{hrs}$, weighed and handly slaughtered. After complete bleeding. Slaughtered animals were de-skinned, dressed out and the hot carcass including head was weighed and recorded. Edible offals; liver, heart, spleen and kidneys, were weighed.

\section{Blood sample collection, haematology and biochemical analysis}

At the end of the feeding period, the animals were starved of feed for 24 hours before blood samples were collected from one rabbit per replicate for haematological and biochemical analysis. Blood samples were collected into labeled Ethylene-Deamine Tetra-Acetic Acid (EDTA) treated tubes for haematological analysis and into tubes without anticoagulant for serum biochemical evaluation. Biochemical analysis in the serum: evaluation of transaminases activities; Total protein; total cholesterol and triglyceride. Biuret method of serum total protein determination was employed in this assay as described by Gornal, et al. [7]. Total cholesterol and triglyceride was determined using colorimetric enzymatic method as described by Trinder, et al. [8]. Alanine amino transferase, Aspartate amino transferase activity was determined using spectrophotometric method [9].

\section{Statistical Analysis}

All data were assembled using Excel 2007. The weights, growth rate, feed conversion ratio feed intake and carcass yield and proportions of the internal organs of the animals were subjected to analysis of variance per a completely randomized design and means were separated by the Duncan's test $[10,11]$.

$$
\gamma \mathrm{i}=\mu+\alpha \mathrm{i}+\mathrm{ei}
$$


Where:

$\gamma \mathrm{i}=$ is the dependent variable (average food consumption, initial average live weight,

final average live weight, average weight gain, feed conversion)

$\mu=$ general mean

$\alpha \mathrm{i}=$ effect of treatments

$\mathrm{ei}=$ Residual error

\section{Result}

\section{Effects of Moringa Oleifera leaf meal (MOLM) on some growth and carcass parameters}

Result of the effect of MOLM on some growth and carcass parameters is shown by (Table 2, 3). The mean feed intake, weight gain and feed conversion ratio are summarized in Table 3 above. Feed intake decreased from $82 \mathrm{~g} /$ day for the control T0 through $74 \mathrm{~g} /$ day in diet T1, to $69 \mathrm{~g} /$ day in diet $\mathrm{T} 2$. The feed intake recorded in diet 2 was significantly smaller $(\mathrm{P}<0.05)$ from those of diets 0 and 1 . Mean growth rates were similar $(\mathrm{P}$ $>0.05$ ) between diet $\mathrm{T} 0$ and $\mathrm{T} 1$ though the tendency was in the decrease $(25,20$ and $20 \mathrm{~g} /$ day). There is no difference $(\mathrm{P}>0.05)$ between the control and the other treatment for initial weigh and feed intake. The highest weigh gain is observed for control which is statistically similar $(\mathrm{P}>0.05)$ to $\operatorname{diet} \mathrm{T} 1$, but different $(\mathrm{P}<0.05)$ to diet $\mathrm{T} 2$.

Table 4 shows the effect of MOLM on carcass. There is no difference $(\mathrm{P}>0.05)$ between the control diet $\mathrm{T} 0$ and the other diet T1 and T2 for heart, liver, lungs weight and carcass length.

\section{Effects of Moringa Oleifera leaf meal (MOLM) on hematological and biochemical parameters}

The blood hematological and biochemical components of the rabbits are shown in (Table 4,5). The MOLM did not vary the blood characteristics and some biochemical parameter studied. However, the MOLM tended to increase the protein level in the blood and white blood cell in T1 with significant difference $(\mathrm{p}<0.05)$.

\begin{tabular}{|c|c|c|c|c|c|c|}
\hline \multicolumn{7}{|c|}{ Table 2: Chemical Composition of Moringa Oleifera Leaf } \\
\hline Specimen & DM (\%) & CP* & $\begin{array}{c}\text { ME } \\
\text { (Kcal/ } \\
\text { DM kg) }\end{array}$ & CF* & EE* & Ash* \\
\hline MOLM & 93.08 & 27.84 & 2918.40 & 11.79 & 7.73 & 9.97 \\
\hline
\end{tabular}

DM: Dry Matter; CP: Crude Protein; ME: Metabolizable Energy; CF: Crude Fiber; EE: Ether Extract

Table 3: Effects of Moringa Oleifera Leaf Meal (MOLM) on Weights, Growth Rate and Feed Intake

\begin{tabular}{|c|c|c|c|}
\hline Parameters & T0 & T1 & T2 \\
\hline Average initial weight $(\mathrm{g}) \pm \mathrm{SEM}$ & $592 \pm 76^{a}$ & $614.5 \pm 39^{\mathrm{a}}$ & $571.9 \pm 39^{\mathrm{a}}$ \\
\hline Mean final weight $(\mathrm{g}) \pm$ SEM & $2012.5 \pm 119^{\mathrm{a}}$ & $1961.5 \pm 214^{\mathrm{a}}$ & $1630 \pm 100^{\mathrm{b}}$ \\
\hline Total weight gain $(\mathrm{g}) \pm \mathrm{SEM}$ & $1420.5 \pm 127^{\mathrm{a}}$ & $1347 \pm 206^{\mathrm{a}}$ & $1058 \pm 96^{b}$ \\
\hline Mean feed intake $(\mathrm{g} / \mathrm{)} \pm \mathrm{SEM}$ & $4633 \pm 627^{\mathrm{a}}$ & $4214 \pm 457^{\mathrm{a}}$ & $4149 \pm 182^{a}$ \\
\hline Feed conversion ratio & $3.25 \pm 0.30^{\mathrm{b}}$ & $3.16 \pm 0.41^{b}$ & $3.93 \pm 0.23^{a}$ \\
\hline $\begin{array}{c}\text { Consumption index relative to metabolic } \\
\text { weight }\end{array}$ & $20 \pm 1.92^{\mathrm{ab}}$ & $19.1 \pm 2.14^{\mathrm{b}}$ & $22.41 \pm 0.92^{\mathrm{a}}$ \\
\hline $\begin{array}{l}\text { mean daily feed intake (g/day) } \pm \\
\text { SEM }\end{array}$ & $82.74 \pm 11^{\mathrm{a}}$ & $74.1 \pm 5.8^{\mathrm{ab}}$ & $69.58 \pm 3.2^{\mathrm{b}}$ \\
\hline $\begin{array}{l}\text { Mean daily growth rate } \\
\text { (g/day) } \pm \text { SEM }\end{array}$ & $25.37 \pm 2.28^{\mathrm{a}}$ & $20 \pm 1.92^{\mathrm{ab}}$ & $20 \pm 1.92^{\mathrm{ab}}$ \\
\hline
\end{tabular}

Table 4: Effects of Moringa Oleifera leaf meal(MOLM) on carcass

\begin{tabular}{|c|c|c|c|}
\hline Parameters & T0 & T1 & T2 \\
\hline Live weight (g) \pm SEM & $1885.7 \pm 88^{\mathrm{a}}$ & $1740 \pm 136^{\mathrm{a}}$ & $1448 \pm 172^{\mathrm{b}}$ \\
\hline dress weight $(\mathrm{g}) \pm \mathrm{SEM}$ & $191.2 \pm 21^{\mathrm{a}}$ & $178.80 \pm 27.8^{\mathrm{ab}}$ & $140 \pm 25.5^{\mathrm{b}}$ \\
\hline carcass weight $(\mathrm{g}) \pm$ SEM & $1010 \pm 61.8^{\mathrm{a}}$ & $923 \pm 71^{\mathrm{a}}$ & $698 \pm 72^{\mathrm{b}}$ \\
\hline Carcass lenght $(\mathrm{g}) \pm \mathrm{SEM}$ & $34 \pm 0.81^{\mathrm{a}}$ & $34.5 \pm 0.58^{\mathrm{a}}$ & $33 \pm 2.1^{\mathrm{a}}$ \\
\hline head weight (g) \pm SEM & $130 \pm 7.07^{\mathrm{a}}$ & $110 \pm 9.12^{\mathrm{b}}$ & $108.8 \pm 9.78^{\mathrm{b}}$ \\
\hline liver weight $(\mathrm{g}) \pm$ SEM & $40 \pm 7.07^{\mathrm{a}}$ & $40 \pm 7.07^{\mathrm{a}}$ & $33.75 \pm 4.78^{\mathrm{a}}$ \\
\hline heart weight (g) \pm SEM & $5 \pm 0^{\mathrm{a}}$ & $5 \pm 0^{\mathrm{a}}$ & $5 \pm 0^{\mathrm{a}}$ \\
\hline kidney weight (g) \pm SEM & $16.25 \pm 4.78^{\mathrm{a}}$ & $12.50 \pm 2.88^{\mathrm{ab}}$ & $8.75 \pm 2.5^{\mathrm{b}}$ \\
\hline lungs weight (g) \pm SEM & $10 \pm 4.08^{\mathrm{a}}$ & $12.5 \pm 8.66^{\mathrm{a}}$ & $10.0 \pm 0.00^{\mathrm{a}}$ \\
\hline
\end{tabular}


Table 5: Effects of Moringa Oleifera leaf meal (MOLM) on biochemical parameters

\begin{tabular}{|c|c|c|c|}
\hline parameters & T0 & T1 & T2 \\
\hline $\mathrm{RBC} 10^{6} / \mathrm{mm}^{3} \pm \mathrm{SEM}$ & $6.7 \pm 0.5^{\mathrm{a}}$ & $6.85 \pm 0.24^{\mathrm{a}}$ & $7.07 \pm 0.5^{\mathrm{a}}$ \\
\hline WBC $\left(10^{3} / \mathrm{mm}^{3}\right) \pm$ SEM & $5.5 \pm 0.92^{\mathrm{b}}$ & $7.34 \pm 6.67^{\mathrm{a}}$ & $6.26 \pm 0.46^{\mathrm{ab}}$ \\
\hline $\mathrm{Hb}(\mathrm{g} / \mathrm{dl}) \pm \mathrm{SEM}$ & $14.1 \pm 0.60^{\mathrm{a}}$ & $14.03 \pm 0.47^{\mathrm{a}}$ & $14.23 \pm 0.9^{\mathrm{a}}$ \\
\hline Platelets $\left(10^{3} / \mathrm{mm}^{3}\right) \pm$ SEM & $369.67 \pm 92.11^{\mathrm{a}}$ & $328.3 \pm 90.27^{a}$ & $329.33 \pm 82.27^{\mathrm{a}}$ \\
\hline hematocrit (\%) \pm SEM & $45.93 \pm 2.18^{\mathrm{a}}$ & $46.4 \pm 1.49^{\mathrm{a}}$ & $46.9 \pm 2.2^{\mathrm{a}}$ \\
\hline VGM (fl) \pm SEM & $68.5 \pm 2.41^{\mathrm{a}}$ & $67.67 \pm 0.68^{\mathrm{a}}$ & $66.5 \pm 1.76^{a}$ \\
\hline MCHC $(\mathrm{g}) \pm$ SEM & $30.7 \pm 0.65^{\mathrm{a}}$ & $30.23 \pm 0.057^{a}$ & $30.33 \pm 0.55^{\mathrm{a}}$ \\
\hline neutrophils (\%) \pm SEM & $32.1 \pm 1.57^{\mathrm{a}}$ & $28.27 \pm 2.59^{\mathrm{a}}$ & $32 \pm 10.56^{\mathrm{a}}$ \\
\hline eosinophils (\%) \pm SEM & $0 \pm 0.00^{\mathrm{a}}$ & $0.03 \pm 0.057^{\mathrm{a}}$ & $0 \pm 0.00^{\mathrm{a}}$ \\
\hline basophils (\%) \pm SEM & $0.93 \pm 00.152^{\mathrm{a}}$ & $0.83 \pm 0.208^{\mathrm{a}}$ & $0.90 \pm 0.96^{a}$ \\
\hline lymphocytes (\%) \pm SEM & $64.53 \pm 1.87^{a}$ & $67.06 \pm 4.62^{\mathrm{a}}$ & $60.43 \pm 10.07^{\mathrm{a}}$ \\
\hline monocytes $(\%) \pm$ SEM & $2.43 \pm 1.93^{\mathrm{a}}$ & $3.8 \pm 1.91^{\mathrm{a}}$ & $5.66 \pm 0.32^{\mathrm{a}}$ \\
\hline \multicolumn{4}{|c|}{$\begin{array}{l}\mathrm{ab}=\text { means on the same row not followed by the same letter are significantly different }(p<0.05) \\
\mathrm{RBC}=\text { Red blood cell, } \mathrm{Hb}=\text { Haemoglobin, } \mathrm{WBC}=\text { White Blood Cell, } \mathrm{MCV}=\text { Mean cell volume, } \mathrm{MCHC}=\text { Mean cell haemoglobin concentration, Mean } \\
\text { Corpuscular Volume }(\mathrm{MCV}) \text { Mean Corpuscular Hemoglobin Concentration }(\mathrm{MCHC})\end{array}$} \\
\hline
\end{tabular}

\section{Discussion}

The rabbits weight gains for $\mathrm{T} 1$ and $\mathrm{T} 2$ diets are different to those obtained (20,1 and 20,1g / day) by Dougnon, et al. and Esong, et al. [2,5]. On the other hand, the average daily weight gain for control feed $(25.37 \mathrm{~g} / \mathrm{d})$ is much higher than those reported by these authors. However, the final body weight showed significant difference $(\mathrm{P}<0.05)$ between the treatment T0, T1 and T3 as high weight gain in animals is normally because of increased feed intake. In this study, there was increase in final body weight and body weight gain and confirm the results of Adeniji and Lawal [12].

The result of the present study suggests that, MOLM when fed as source of protein graded level up to $25 \%$ could promate the growth of rabbit. In the same time, certain adverse effect could be happened with dosage of moringa $50 \%$ due to the high content of some phytochemical compounds (phenols, cumares, alkaloids and tanins) which are naturally occurring at high levels of MOLM [13]. Ufele, et al. show also that Moringa oleifera leaf meal is non-toxic to rabbits at the $20 \%$ level of inclusion [14].
Blood is an important index of physiological and nutritional status in the organism [15]. The effect of MOLM on selected enzymes showed any effect in the activities of aspartate transaminase and alanine transaminase. Transaminase are enzyme markers of hepatic toxicity. There were no significant differences between the tests and control groups for Cholesterol, urea and creatinine. This finding suggests that the MOLM may not have negative effect on the proper functioning of the liver, kidney and muscle. The biochemical values of total protein (59, $2-64,7 \mathrm{~g} / \mathrm{l})$, reported in this study Table 3 were generally higher in other tropical areas. The generally higher biochemical values in this study could be due to the high nutritional value of the moringa.

There were no differences between control and test diet for haematological parameters except WBC which suggest that the MOLM could enhance hematopoietic activity and may not precipitate anaemia in a biologic system [16]. The (Mean Corpuscular Volume) MCV, MCH, MCHC, Neutrophils, Lymphocyte, Monocytes and Eosinophils were not significantly affected (P > 0.05 ) with the inclusion of Moringa leaf meal. This report agrees 
with the findings of Olatunji and Alagbe, when rabbits were fed vary level MOLM of and the normal range established by Mitruka and Rawnsley $[17,18]$.

The nonsignificant difference $(\mathrm{P}>0.05)$ observed for this parameter is an indication of better utilization of MOLM by the rabbits. The higher value of WBC observed in rabbits fed MOLM based diets compared with the control is an indication that the immunity levels of the rabbits were challenged, which is different from those obtain by Odetola, et al. [19]. According to Soetan, et al. high counts of WBC enhance adaptability to local environment and disease prevalent conditions [20].

The Red blood cell values were not significantly (P > 0.05 ) influenced with the inclusion of Moringa leaf meal, this means that shows that oxygen and carbon dioxide are well distributed in the body to enhance respiration and good health status. The values recorded fall within the normal recorded by $\mathrm{Mi}-$ truka and Rawnsley and it agrees with findings of Odetola, et al. $[18,19]$.

\section{Conclusion}

This study has demonstrated that Moringa oleifera leaf meal possess good dietary protein quality for optimal growth of rabbits. It could be used to improve daily weight gain and feed intake of rabbits. And also MOLM can be used to replace such sources protein like soya bean meal and groundnut cake in the rabbit's diet up to $25 \%$ inclusion level without any detrimental effect on the performance, haematology and serum biochemistry of rabbits.

\section{References}

1. Ahemen T, Abu AH, Iorgilim LK. Physiological responses of rabbits fed graded levels of Moringa oleifera leaf meal (MOLM): Some aspects of haematology and serum biochemistry Arch. Appl. Sci. Res. 2013;5(2):172-176.

2. Esong RN, Etchu AK, Bayemi PH, Tan PV. Effects of the dietary replacement of maize with sun-dried cocoa pods on the performance of growing rabbits Tropical. Anim Health Prod. 2015;47(7):1411-1416. doi: 10.1007/s11250-015-0879-3

3. Foidl N, Makkar HPS, Becker K. Potentiel de Moringa Oleifera en agriculture et dans l'industrie. Potentiel de développement des produits de Moringa. 2001;29 octobre - 02 novembre Dar es salam,Tanzanie consulté le 28 juillet

4. Tedonkeng PE, Niba AT, Fonteh FA, Tedonkeng F, Kana JR, Boukila B, et al. Effet de la supplémentation au Moringa oleifera ou au blocs multinutritionnels sur l'évolution du poids post partum et la croissance pré-sevrage des cobayes (CaviaporcellusL.). Livestock Res Rural Dev. 2005;17(4).

5. Dougnon T], Aboh BA, Kpodékon TM, Honvou S, Youssao. Effects of substitution of pellet of Moringa oleifera to commercial feedon rabbit's digestion, growth performance and carcass trait. J. appl. pharm. sci. 2012;2(9):015-019.

6. Ekalle NM, Mongo BG, Ghomsi MOS, Tientcheu BL, Tchakounte J, Hakoue F, et al. Substitution of Groundnut Cake with Palm Kernel Cake on the Growth Performance of Broilers. J J Agriculture. 2016;2(1):007

7. Gornall AG, Bardwill GS, David MM. Determination of serum proteins by means of Biuret reactions. J Biol Chem. 1949;177(2):751-766

8. Trinder P. Estimation of triglycerides in blood GPO-PAP enzymatic method. American clinical Biochemical. 1969;6:24-7.

9. Reitman S and Frankel S. A colorimetric method for the determination of serum Oxaloacetic pyruvic transaminases. Am J Clin Pathol. 1957;28(1):56-63

10. SAS, Statistical Analyses System. (SAS) Institute Inc, Cary NC, USA; 2002.

11. Mead R, Curnow RN. Statistical methods in agriculture and experimental biology. London: Chapman and Hall; 2013.

12. Adeniji A.A, Lawal M. Effects of Replacing Groundnut Cake with Moringa oleifera Leaf Meal in the Diets of Grower Rabbits. International Journal of Molecular Veterinary Research. 2012;2(3):8-13. doi: 10.5376/ ijmvr.2012. 02.0003

13. El-Badawi A.Y, Omer H.A.A, Abedo A.A, Yacout M.H.M. Response of Growing New Zealand White Rabbits to Rations Supplemented with Different Levels of Moringa oleifera Dry Leaves. Global Veterinaria. 2014;12(4):573-582. doi: 10.5829/idosi.gv.2014.12.04.8380

14. Ufele AN, Ebenebe CI, Igwe II, Mogbo TC, Akunne EC, Aziagba BO. The Effects of Drumstick Tree (Moringa oleifera) Leaf Meal on the Average Weight Gain of Domestic Rabbits (Oryctolagus cuniculus. The Bioscientist. 2013;1(1):106-108

15. Olorode, BR, Adeniran, RA, Abiola, JO. Effect of graded levels of Moringa oleifera seed meal on haematological values and organ weight of broiler chicken. Tropical J. Animal Sci. 2007;10(1-2):63-67.

16. Isitua CC, Ibeh IN. Toxicological Assessment of Aqueous Extract of Moringa Oleifera and Caulis Bambusae Leaves in Rabbits. J Clinic Toxicol. 2013;S12:003. doi:10.4172/2161-0495.S12-003

17. Olatunji AK, Alagbe OJ, Hammed M A. Effect of Varying Levels of Moringa Oleifera Leaf Meal on Performance and Blood Profile of Weaner Rabbits. International Journal of Science and Research. 2016;5(6).

18. Mitruka BM, Rawnsley HM. Clinical biochemical and hematological reference values in normal experimental animals. USA: Masson Publishing Inc; 1977:134-135

19. Odetola MO, Ewuola OE, Olufemi A. Heamatology serum biochemistry and organ histopathology of rabbits fed graded levels of whole kenal (hibiscus canabinus) seed meal. Int. J. Environ. Agric. Res. 2012;7(2):86-92. doi: 10.3923/ijar.2012.86.92

20. Soetan et al. Preliminary studies on the hematological parameters of cockerels fed raw and processed guinea corn (Sorghum bicolor). Proceedings of 38th Annual Conference of Nigerian Society for Animal production. 2013;p.49-52. 